\title{
PRODUCT DEVELOPMENT OF LOW SUGAR READY-TO-DRINK (RTD) SOY JELLY DRINK
}

Tabligh Permana

Jessline Ramaputra

Filiana Santoso
Department of Food Technology, Faculty of Life Sciences and Technology, Swiss German University, Indonesia, 15143

\begin{abstract}
Soymilk was processed into a nutritious jelly drink product with low sugar level to overcome the problems of current comercial jelly drink. The optimum concentration of iotacarrageenan $(0.1-0.3 \%)$ was determined based on sensory evaluation and texture analysis. The preferable sweetness level (2.5-7.5\%) was determined based on sensory evaluation. The optimum combination of stevia and sucrose $(\mathrm{g} / \mathrm{l}, 0.211: 45,0.27: 45,0.579: 45,0: 75)$ was determined based on sensory evaluation. The effect of the heating time $(30-60 \mathrm{~min})$ and the effect of storage temperature $\left(4\right.$ and $25^{\circ} \mathrm{C}$ ) were evaluated by using product characteristic and microbial activity. Results presented in this work suggest that iota-carrageenan was more suitable to be used to produce RTD soy jelly drink than kappa-carrageenan, with $2 \%$ addition as the optimum concentration. The combination of $4.5 \%$ sucrose and $0.0579 \%$ stevia could produce less sugar RTD soy jelly drink with good sensory acceptance. Standard heating process (30 minutes) could hold the microbial activity below the maximum limit up to 21 day at $4{ }^{\circ} \mathrm{C}$ storage condition, but only has 6 hours at $25{ }^{\circ} \mathrm{C}$ storage condition. The additional heating time could hold up to about 11 hours. The heating process could increase the texture value of product, and the texture characteristic product would be changing during storage at $4{ }^{\circ} \mathrm{C}$.
\end{abstract}

Keywords: Carrageenan, jelly drink, ready-to-drink, soybean, stevia

\begin{abstract}
ABSTRAK
Susu kedelai diproses untuk menjadi minuman jelly yang bernutrisi dan rendah gula untuk menyelesaikan masalah produk-produk komersial yang sudah ada. Konsentrasi iota-karagenan optimal $(0,1-0,3 \%)$ didapatkan berdasarkan analisis evaluasi sensori dan analisis tekstur. Tingkat rasa manis yang disukai $(2,5-7,5 \%)$ ditetapkan berdasarkan evaluasi sensori. Kombinasi optimal penambahan stevia:sukrosa (g/l, 0,211:45, 0,27:45, 0,579:45, 0:75) didapatkan berdasarkan analisis evaluasi sensori. Efek waktu pemanasan (30-60 menit) dan suhu penyimpanan (4 dan 25 $\left.{ }^{\circ} \mathrm{C}\right)$ dievaluasi berdasarkan parameter karakteristik produk dan aktivitas mikroba. Hasil penelitian ini menunjukan bahwa iota-karagenan lebih cocok digunakan untuk produksi RTD soy jelly drink dibandingkan dengan kappa-karagenan, dengan konsentrasi optimal adalah $2 \%$. Kombinasi 4,5\% sukrosa dan $0,0579 \%$ stevia dapat menghasilkan RTD soy jelly drink yang rendah gula namun tetap memiliki penerimaan rasa dan penerimaan umum yang baik. Pemanasan standar (30 menit) mampu menahan nilai aktivitas mikroba tetap dibawah batas maksimal sampai 21 hari pada penyimpanan $4{ }^{\circ} \mathrm{C}$. namun pada penyimpanan $25^{\circ} \mathrm{C}$ hanya selama 6 jam. Waktu pemanasan tambahan mampu menahan selama sekitar 11 jam. Proses pemanasan dapat menyebabkan peningkatan nilai tekstur produk, dan karakteristik tekstur produk juga dapat berubah bila produk disimpan di suhu $4{ }^{\circ} \mathrm{C}$.
\end{abstract}

Kata kunci: Jelly drink, karagenan, kedelai, ready-to-drink, stevia
Article Information

Article Type: Research Article

Journal Type: Open Access

Volume: 2 Issue 1

Manuscript ID

v2n1384-2

Received Date

06 July 2020

Accepted Date

23 August 2020

Published Date

31 August 2020

DOI:

DOI:
10.33555/jffn.v2i1.41

Corresponding author: Tabligh Permana

Tangerang Indonesia, 15143 Email:

tabligh.permana@sgu.ac.id

Citation:

Permana, T., Ramaputra, J., Santoso, F. 2020. Product Development of Low Sugar Ready-to-Drink (RTD) Soy Jelly Drink. J. Functional Food \& Nutraceutical, 2(1), pp.43-52.

Copyright: $@ 2020$ Swiss German University. This is an open-access article distributed under the terms of the Creative Commons Attribution 4.0 International License, which permits unrestricted use, License, which permits unrestricted use,
distribution and reproduction in any medium, provided the original author and source are credited. 


\section{INTRODUCTION}

Jelly drink is a ready to drink beverage that was firstly created as a snack to delay hunger that contains water, sweeteners, carrageenan (that creates jelly texture), artificial flavoring, sweetener, and coloring that create an end product with some unique characteristics such as chewy and sippable by straw (Agustin and Putri, 2014; Nuraeni et al., 2019). However, this product is lacking nutritional value.

People nowadays are getting busier with their work and in need of something practical yet nutritious to temporarily replace their meal with something that is able to delay hunger without disturbing their work time. People also tend to be concerned about the sugar level contained in a product (Sardarodiyan and Hakimzadeh, 2016). By developing the common jelly drink to be more nutritious and less sugar content but still practical, it will surely overcome those problems.

Soy milk extracted from soya bean or Glycine max $L$. is known to be good for human's general nutrition as the protein source (Shurtleff and Aoyagi, 2016). Many studies have reported the beneficial impacts of the addition of soya bean's derivatives to other food products, such as reducing the risk of coronary heart disease and treatment for iron deficiency. The nutritional content that has the role on the beneficial of soymilk are iron, protein, and amino acids (Baba et al., 2005; Hugelshofer, 1986; Setyaningrum et al., 2017). Regarding that nutritional content, soymilk could be processed into a nutritious jelly drink product.

The combination of sugar with stevia has a potential to produce soy milk jelly drink products with less sugar content but still high in sensory acceptance (Gasmalla et al., 2014; Saniah and Samsiah, 2012; Takaichi and Hatai, 1998). Formulation the proper combination ratio of sugar with stevia is important to be known to achieve that condition.

To make a jelly drink product, carrageenan can be used because of its ability as a gel-forming agent (Kaya et al., 2015). Jelly drink texture is different from normal jelly products because it should be firm enough to form a jelly but soft enough to be sipped using straw with a little amount of syneresis presence (Hartati and Djauhari, 2017). It is important to know the optimum concentration of carrageenan addition to produce soy milk jelly drink products with good texture characteristics.

Microbes tend to grow rapidly in soybean-based products, and soy milk jelly drink has a similar problem. Heating treatment could kill bacteria and prolong the shelf-life of a soy milk product (Kohli et al., 2017). Heating process also takes place in the production of soy milk jelly drink to activate the gelling properties of carrageenan, and producing jelly texture. The observation of the effect of the heating process to the texture characteristic, microbial number, and stability during storage of RTD soy jelly drink product is important.

In this context, the objectives of this work were to determine the optimum concentration of carrageenan addition, the optimum combination ratio of sugar with stevia, and to evaluate the effect of heating process to the texture characteristic, microbial activity, and stability during storage. The parameters used were sippable and microscopic observations. The optimum concentration of iota carrageenan was obtained from analysis of sensory evaluation and texture analysis parameters. The preferable sweetness level of RTD soy jelly drink was determined from analysis of sensory evaluation parameter. The optimum combination of stevia and sucrose to produce less sugar-RTD soy jelly drink was obtained from the analysis of sensory evaluation parameters.

\section{MATERIALS AND METHOD}

\section{Materials}

Materials to produce soy milk were soybean (Cap BOLAM), Baking Soda (NaHCO3, Koepoe Koepoe), and mineral water. While the materials to produce low sugar Ready to Drink soy jelly drink were soy milk, sucrose (Gulaku), stevia (Steviol), iota-carrageenan (technical grade), kappacarrageenan (technical grade), and aluminum laminated pouch. 


\section{Method}

\section{Soy milk production}

The selected soybeans were soaked in $\mathrm{NaHCO} 3$ solution $(0.5 \% \mathrm{w} / \mathrm{w})$ for $8 \mathrm{~h}$ minimum in room temperature. The soaked soybeans were drained and washed using clean water. The soybeans skins were separated from its kernel. The soybeans kernels were collected and blanched in boiling water for $30 \mathrm{~min}$. One hundred $\mathrm{g}$ of blanched soybeans were grinded with $600 \mathrm{~g}$ of hot water (80$90{ }^{\circ} \mathrm{C}$ ) for $2 \mathrm{~min}$ at high speed. The grinded soy milk slurry was filtered through a strainer and clean kitchen towel (Nirmagustina and Rani, 2013).

\section{Jelly drink production and preliminary analytical stage}

Soy milk, carrageenan, sugar, and stevia were mixed and heated at $90{ }^{\circ} \mathrm{C}$ for $30 \mathrm{~min}$. This process also aimed to be the pasteurization process of the product. Specifically to evaluate the effect of the heating process, 2 additional heating times were conducted (15 and $30 \mathrm{~min}$ ). After the product was heated, the product was poured into cups (for analysis) or packed and sealed into pouches directly after to prevent microbial contamination. The products were chilled in the refrigerator for 4-6 $\mathrm{h}$ minimum to let the gelling process complete. At the preliminary analytical stage, the production used two types of carrageenan (iota-carrageenan and kappa-carrageenan), in four concentrations of carrageenan addition $(0.3,0.4,0.5,0.6 \% \mathrm{w} / \mathrm{v})$, and used $5 \%$ of sugar concentration. Products from all combinations were tested for sippable test and microscopic observation to determine the carrageenan type and concentration used for further analytical stages.

\section{Sippable test}

The products from two types of carrageenan in preliminary analytical stages were tested by using the straw of commercial jelly drink. The samples were sucked through the straw to check whether the samples were able to be sipped or not.

\section{Microscopic observation}

The product from two types of carrageenan were observed by using stereo microscope with objective lens magnification: $4.5 \mathrm{X}$, and ocular lens magnification: 16X. The analysis was used to determine the suitable carrageenan type to be used for RTD soy jelly drink production.

\section{Texture analysis}

Three different iota-carrageenan concentrations $(0.1 \%, 0.2 \%, 0.3 \%)$ on day of production (day 0 at $4{ }^{\circ} \mathrm{C}$ ) were measured by Penetrometer and statistically analyzed with ANOVA. The result was used to determine the Optimum Carrageenan Concentration.

Texture of chosen carrageenan concentration was analyzed by Penetrometer. The analysis was done after the heating process, and during 3 weeks storage, at $4{ }^{\circ} \mathrm{C}$ and $25{ }^{\circ} \mathrm{C}$ of storage condition. Then the result was statistically analyzed with nonparametric analysis. The analysis was done to evaluate the effect of the heating process to the texture characteristic, microbial activity, and stability during storage.

\section{Sensory evaluation}

The hedonic test was used to determine the optimum concentration of carrageenan addition (sample: $0.1 \%, 0.2 \%, 0.3 \%$ ), evaluation of preferred sweetness level of RTD soy jelly drink (sample: $2.5 \%, 5 \%, 7.5 \%$ ), and the optimum combination ratio of sugar with stevia (stevia:sucrose, g/l, 0.211:45, 0.27:45, 0.579:45, $0: 75)$. The panelists involved in this work were 30 students and laboratory staff from Swiss German University Faculty of Life Science and Technology that were familiar with commercialized jelly drink products. Sensory evaluations using Hedonic tests were statistically analyzed with Friedmann's test and Wilcoxon test with 0.05 as the probability level based on overall likeness of the product using 9points hedonic test where 1 represents "like extremely" and 9 represents "dislike extremely". 


\section{PH and brix value}

The $\mathrm{pH}$ analysis was done by Digital $\mathrm{pH}$ meter and Brix value analysis was done by Refractometer. The analysis was applied to evaluate the stability of the product during 3 weeks storage time, at $4{ }^{\circ} \mathrm{C}$ and $25^{\circ} \mathrm{C}$ of storage condition.

\section{Microbial activity analysis (SNI 2897:2008)}

The microbial activity that was represented by Total Plate Count (TPC) Analysis, and compared to Indonesia National Standard of TPC parameter for jelly drink (104 colony/g). Media used for Total Plate Count Analysis was Plate Count Agar using the Pour Plate method. $25 \mathrm{~g}$ of sample was diluted to $225 \mathrm{ml}$ 0.1\% Buffered Peptone Water (BPW) and homogenized. Then $1 \mathrm{ml}$ of the solution was diluted into $9 \mathrm{ml}$ of BPW as dilution factor 10-1. The diluted sample was again diluted until dilution factor 10-5 was obtained. $1 \mathrm{ml}$ sample from each dilution was poured into a sterilized petri dish. About 12-15 ml of sterilized Plate Count Agar (PCA) was poured into each petri dish and 8figured motion was done to homogenize the sample.
After the agar was set, the petri dish was turned upside down, sealed with Parafilm $\mathrm{M}$ and incubated in $37 \pm 1{ }^{\circ} \mathrm{C}$ for $48 \mathrm{~h}$. Colonies of microbes from range 25-250 were counted as colony form units $(\mathrm{CFU}) / \mathrm{ml}$, and converted to colony/g. The microbial analysis was applied to evaluate the effect of heating process and storage.

\section{RESULTS AND DISCUSSION}

\section{Preliminary analytical stage}

The result shown on Table 1 , that the texture characteristic of kappa-carrageenan product at all concentrations caused the product could not be sipped. For the iota-carrageenan product, $0.3 \%$ of iota-carrageenan concentration was the only one that sippable. It means the maximum concentration of iota-carrageenan used for the further analysis was $0.3 \%$. Jelly drink production from other raw materials, such as Averrhoa blimbi L. (Agustin and Putri, 2014) and soursop fruit (Gani et al.) could produce good texture characteristics by using both kappa or iota-carrageenan.

Table 1. Sipping Capaability Evaluation of Soy Jelly Drink Using Iota- and Kappa-Carrageenan in Several Concentration

\begin{tabular}{|c|c|c|c|}
\hline Concentration & Iota-Carrageenan & Kappa-Carrageenan & Conclusion \\
\hline $0.3 \%$ & Able to be sipped & Not able to be sipped & \multirow{4}{*}{$\begin{array}{c}\text { maximum concentration } 0.3 \% \\
\text { range: } 0.1 \%, 0.2 \%, 0.3 \%\end{array}$} \\
\hline $0.4 \%$ & Not able to be sipped & Not able to be sipped & \\
\hline $0.5 \%$ & Not able to be sipped & Not able to be sipped & \\
\hline $0.6 \%$ & Not able to be sipped & Not able to be sipped & \\
\hline
\end{tabular}

Regarding its molecular structure in the normal condition, gel characteristic of iota-carrageenan is less-rigid texture than kappa-carrageenan (MedianTorres, 2003). Mineral content in the food added with carrageenan could give effect to the gel characteristic of carrageenan.

The potassium ions in soy milk would interact with kappa-carrageenan and produce firmer texture that was hard to sipped. The calcium ions in soymilk could interact with iota-carrageenan and produce soft elastic gel that is sippable (Popescu et al., 2007).

Iota type carrageenan was chosen because it was jelly-like, sippable by straw and there was a presence of syneresis. While the kappa-carrageenan was sticky, too hard to sip, and starchy. The texture 
appearance from microscopic observation can be seen on Figure 1.

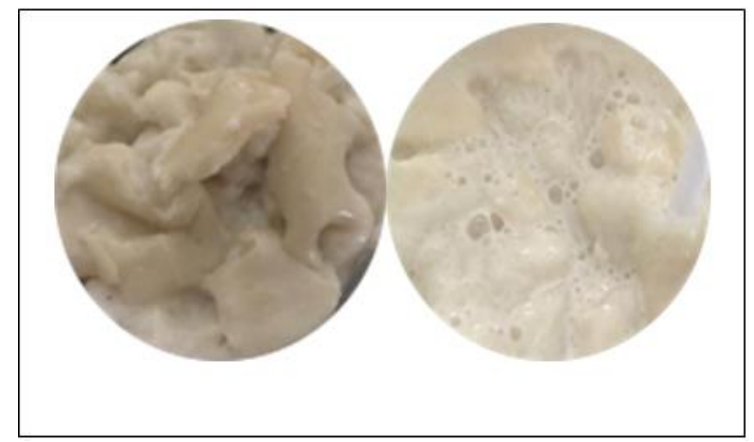

Figure 1. Microscopic visual character of soy jelly drink using (a) kappa-carrageenan, (b) iotacarrageenan

\section{Determination of the optimum iota-carrageenan concentration}

Table 2 shows that the increase of Iota-carrageenan Concentration could increase the texture value of products exponentially $(\mathrm{R} 2=0.9922)$. The texture value would be highly increasing at the iotacarrageenan concentration more than $13 \%$, which led to lower sippability of product. The data also shows that the maximum texture value for the sippable product is $15.00 \pm 0.37 \mathrm{~N}$. Iotacarrageenan tends to set after the heating process at $40-70{ }^{\circ} \mathrm{C}$, the gel-strength ability of the carrageenan increases as the heating process takes place (Thomas, 1997).
The sensory hedonic test was observed only based on the texture profile of the product. Table 2 also shows that $0.2 \%$ of iota-carrageenan is highly preferred by the consumers as jelly drink products much higher than 0.1 and $0.3 \%$ carrageenan concentrations. The product with $0.3 \%$ iotacarrageenan was too firm and hard to be sipped, though still sippable. The product with $0.1 \%$ iotacarrageenan was too thin in texture, and it was not firm enough to be categorized as a jelly drink.

It can be concluded that RTD soy jelly drink product with texture value $7.0 \pm 0.35 \mathrm{~N}$ was highly accepted by the consumers because of its characteristic that was solid enough yet still be able to be sipped using a straw. Those texture characteristics could be achieved by the addition of $0.2 \%$ iota-carrageenan

\section{The optimum combination ratio of sugar with stevia}

According to BPOM regulation (BPOM No. 13:2016 - "Pengawasan Klaim Pada Label dan Iklan Pangan Olahan"), a product can be claimed as "Less Sugar Product" if the product consists of less than $2.5 \%$ sugar in liquid form or less than 5 $\%$ in solid form. While the jelly drink is a semisolid form product, it should contain less than $5 \%$

of sugar to be claimed as a less sugar product (BPOM, 2016).

Table 2. Firmness value and hedonic score for texture of soy jelly drink using iota-carrageenan with concentration

\begin{tabular}{ccc}
\hline Iota-carrageenan $(\%)$ & Firmness value $(\mathbf{N})$ & Hedonic score for texture attribute \\
\hline 0.1 & $4.0 \pm 0.32^{\mathrm{a}}$ & $4.77 \pm 2.19^{\mathrm{a}}$ \\
0.2 & $7.0 \pm 0.35^{\mathrm{b}}$ & $7.30 \pm 1.39^{\mathrm{b}}$ \\
0.3 & $15.0 \pm 0.37^{\mathrm{c}}$ & $4.83 \pm 2.41^{\mathrm{c}}$ \\
\hline
\end{tabular}

Table 3 shows that the concentration of sucrose 5.0 and $7.5 \%$ gave the preferable sweet taste in the same level, but $2.0 \%$ sucrose gave an un- preferable sweet taste. Each concentration of sucrose also gave different texture to the product as answered by 30 out of 30 panelists stated that 
higher concentration of sucrose gave firmer texture. Since the sweetness profile of 5.0 and 7.5 $\%$ of sucrose were similar, all panelists preferred to consume the product with $7.5 \%$ sucrose. Therefore, $7.5 \%$ sucrose concentration was chosen as the most desired RTD soy jelly drink sweetness profile in this stage, and chosen as the sweetness level target on the optimization of combination ratio of sugar with stevia.

Table 3. Hedonic score for taste attribute of soy jelly drink using several concentration of sucrose

\begin{tabular}{ll}
\hline Sucrose concentration $(\%)$ & Hedonic score for taste attribute \\
\hline 2.5 & $4.43 \pm 2.06^{\mathrm{a}}$ \\
5.0 & $6.51 \pm 1.87^{\mathrm{b}}$ \\
7.5 & $7.11 \pm 2.22^{\mathrm{b}}$ \\
\hline
\end{tabular}

Since $5 \%$ is the limitation of less sugar product, $4.5 \%$ of sucrose was used as the maximum level of sucrose concentration in sweetener combination with stevia. The three combinations of stevia and sucrose $(\mathrm{g} / \mathrm{l})$ respectively were $0.211: 45$ (Gasmalla, Yang and Hua, 2014), 0.579:45 (Saniah and Samsiah, 2012), 0.27:45 (Takaichi and Hatai, 1998), where all of them were categorized a lesssugar product.

Table 4 shows that the combination ratio stevia:sucrose 0.579:45 (g/l) and standard had the similar taste and overall acceptance, even though the aroma and texture were different. This result also shows that $3 \%$ of sucrose in the product could be substituted by $0.0579 \%$ of stevia addition. Since the amount of sugar used in the final product is less than 5\%, the product could be claimed as less sugar product. Based on data, the desired composition to RTD soy jelly drink was $0.2 \%$ iota-carrageenan with combination of $4.5 \%$ sucrose and $0.0579 \%$ stevia.

Table 4. Hedonic evaluation of soy jelly drink using several combination ratio of stevia and sucrose

\begin{tabular}{clccc}
\hline \multirow{2}{*}{$\begin{array}{c}\text { Sensory attribute } \\
\text { evaluated }\end{array}$} & \multicolumn{4}{c}{ Hedonic score in soy jellydrink that is using stevia and sucrose with combination ratio $(\mathrm{g} / \mathbf{l})$} \\
\cline { 2 - 4 } & $\mathbf{0 . 2 1 1 : 4 5}$ & $\mathbf{0 . 2 7}: \mathbf{4 5}$ & $\mathbf{0 . 5 7 9 : 4 5}$ & $\mathbf{0 : 7 5}$ (standard) \\
\hline Aroma & $6.73 \pm 1.34^{\mathrm{a}}$ & $6.83 \pm 1.33^{\mathrm{b}}$ & $6.90 \pm 1.51^{\mathrm{c}}$ & $6.90 \pm 1.45^{\mathrm{d}}$ \\
Taste & $5.93 \pm 1.48^{\mathrm{a}}$ & $5.97 \pm 1.48^{\mathrm{a}}$ & $7.20 \pm 1.45^{\mathrm{b}}$ & $7.43 \pm 1.60^{\mathrm{b}}$ \\
Texture & $6.77 \pm 1.79^{\mathrm{a}}$ & $6.63 \pm 1.82^{\mathrm{b}}$ & $6.90 \pm 1.66^{\mathrm{c}}$ & $6.90 \pm 1.96^{\mathrm{d}}$ \\
Overall & $6.13 \pm 1.67^{\mathrm{a}}$ & $5.77 \pm 1.84^{\mathrm{a}}$ & $6.87 \pm 1.70^{\mathrm{b}}$ & $7.23 \pm 1.73^{\mathrm{b}}$ \\
\hline
\end{tabular}

\section{Effect of heating process}

Table 5 shows that the standard heating time (30 min) was able to kill the microbial activity in the products. The maximum of microbial contamination based on SNI about "Jelly Agar" products is 104 colony/g (Standar Nasional Indonesia, 1994). From the result, it also could be

concluded that heating time on 30 min created an edible and safe-to-consume soy milk jelly drink product. Table 5 also shows that the standard 
heating time could produce RTD soy jelly drink with shelf life at $4{ }^{\circ} \mathrm{C}$ storage temperature up to 21 days. As on day 28 , the presence of moulds were detected.

Table 5. Total microbial count (colony/g) of soy jelly drink with 30, 45, and 60 min heating treatment during 28 days storage at $4{ }^{\circ} \mathrm{C}$

\begin{tabular}{|c|c|c|c|}
\hline \multirow{2}{*}{ Storage time (day) } & \multicolumn{3}{|c|}{$\begin{array}{c}\text { Total microbial count of soy jelly drink that receive ........ } \\
\text { heating treatment }\end{array}$} \\
\hline & $30 \mathrm{~min}$ & $45 \mathrm{~min}$ & $60 \mathrm{~min}$ \\
\hline 0 & $<900$ & $<900$ & $<900$ \\
\hline 7 & $<900$ & $<900$ & $<900$ \\
\hline 14 & $<900$ & $<900$ & $<900$ \\
\hline 21 & $<900$ & $<900$ & $<900$ \\
\hline 28 & TNTC ** & - & - \\
\hline
\end{tabular}

\section{NOTE:}

900 -> no microbes appeared; Accept Standard

** Mould appeared

- no data

Figure 2 shows that even though the heating process could produce RTD soy jelly drink with no microbes appearing on microbial activity tests, the microbes would be growing rapidly if the product was stored at $25{ }^{\circ} \mathrm{C}$. The shelf life was only $6 \mathrm{~h}$. The additional $15 \mathrm{~min}$ of heating time could prolong the shelf life up to about $11 \mathrm{~h}$, but the more heating time addition (30 min) could not give an additional impact to the shelf life.A study showed preservation by high-pressure processing treatment was more effective to kill aerobic and anaerobic bacteria in soy milk product (Kohli et al., 2017). It might be caused by the insufficient heat temperature treated to the product so the spores of microbes from the original sample or the packaging itself tend to grow rapidly at $25{ }^{\circ} \mathrm{C}$ storage temperature. Another method of the production process should be considered to get a longer shelf life of RTD soy jelly drink products that are able to be stored at $25^{\circ} \mathrm{C}$.

Table 6 shows that the increase of heating time could increase the texture value of the product, while the result of $\mathrm{pH}$ and Brix value were not significantly changed. The strength of carrageenan gel is increasing as the increase of temperature, and will be decreasing when the temperature of heating

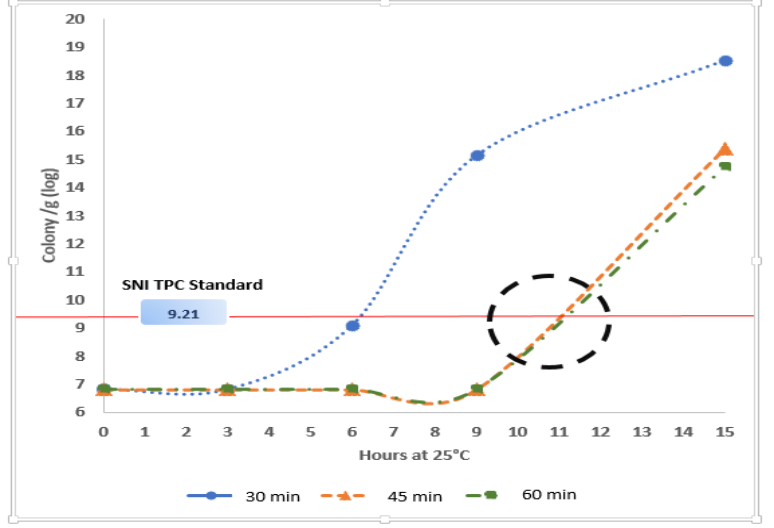

Figure 2. Total microbial count (log colony/g) of soy jelly drink with 30,45 , and $60 \mathrm{~min}$ heating treatment during $16 \mathrm{~h}$ Storage at $25^{\circ} \mathrm{C}$

has reached the temperature around $110{ }^{\circ} \mathrm{C}$ (Tziboula and Horne, 2000). The heat will alter the networks chain of gel, and at the certain heating condition the gel strength will be lost due to the loss of networks chain of gel (Ainsworth and Blanshard, 1879) . In this work, the temperature used for production was $90{ }^{\circ} \mathrm{C}$, and it was still under $100{ }^{\circ} \mathrm{C}$ as the maximum temperature of carrageenan heat treatment. This heating condition still gave the positive impact to the gel strength of the product. The increase of texture value has a 
potential to change the sensory acceptance and sippability of the product. Unfortunately, this work has no data regarding the sensory evaluation of products on different heating times.

Table 6. Firmness, acidity, total solid, and microbial count of soy jelly drink with 30,45 , and 60 min heating treatment

\begin{tabular}{lllll}
\hline Heating Time $(\mathbf{m i n})$ & Firmness Value $(\mathbf{N})$ & Acidity $(\mathbf{p H}$ value $)$ & Total Solid $(\%$ Brix $)$ & Total microbial count $($ colony/g) \\
\hline $\mathbf{3 0}$ (standard) & $8.0 \pm 0.69^{\mathrm{a}}$ & $7.3 \pm 0.05^{\mathrm{a}}$ & $3.5 \pm 0.00$ & $<900$ \\
$\mathbf{4 5}$ & $9.8 \pm 0.39^{\mathrm{b}}$ & $7.0 \pm 0.11^{\mathrm{b}}$ & $3.5 \pm 0.00$ & $<900$ \\
$\mathbf{6 0}$ & $12.1 \pm 0.65^{\mathrm{c}}$ & $7.1 \pm 0.121^{\mathrm{c}}$ & $3.5 \pm 0.00$ & $<900$ \\
\hline
\end{tabular}

Figure $3 \mathrm{~A}$ and $\mathrm{B}$ show that the texture characteristics of products with standard heating processes during storage at $4{ }^{\circ} \mathrm{C}$ were changing. Based on data, the texture of products was still under the maximum acceptability limit $(15.0 \mathrm{~N})$

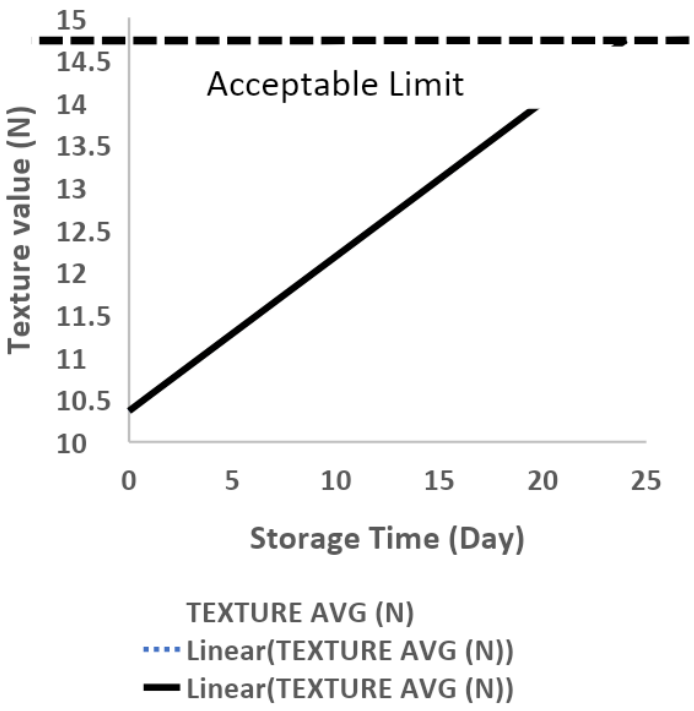

A until day 21, even though the texture was becoming harder. This changing characteristic was caused by the condition that water inside gel formcarrageenan was moved out from the solid matrix, producing a harder gel form and higher syneresis value of product.

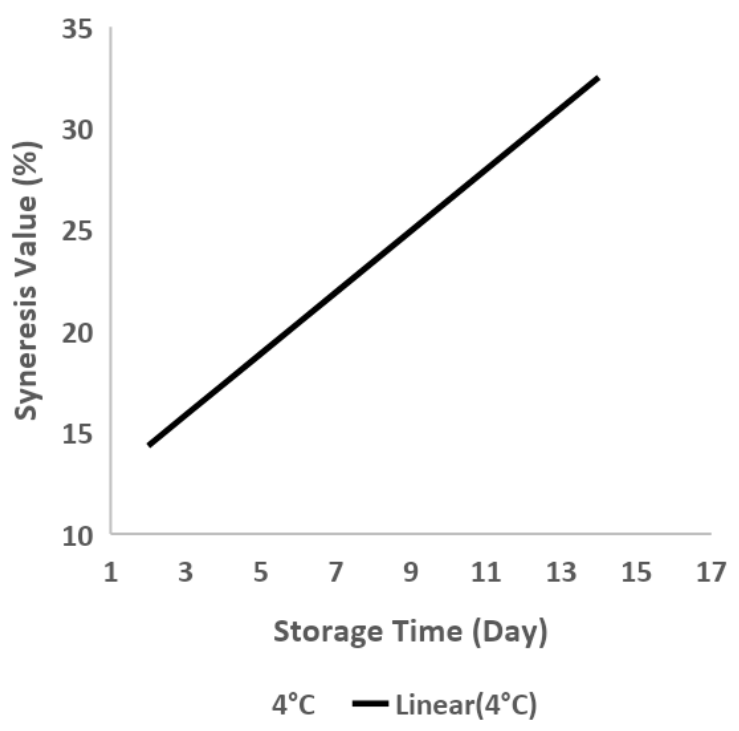

B

Figure 3. Trend lines of (A) texture stability and (B) syneresis; during storage at $4{ }^{\circ} \mathrm{C}$

\section{CONCLUSION}

Results presented in this work suggest that iotacarrageenan was more suitable to be used to produce RTD soy jelly drink than kappacarrageenan, with $2 \%$ addition as the optimum concentration. The combination of $4.5 \%$ sucrose and $0.0579 \%$ stevia could produce less sugar RTD soy jelly drink with good sensory acceptance. Standard heating process could hold the microbial activity below the maximum limit up to 21 day at 4 ${ }^{\circ} \mathrm{C}$ storage condition, but only has $6 \mathrm{~h}$ at $25{ }^{\circ} \mathrm{C}$ 
storage condition. Additional heating time could hold the microbial activity below the maximum limit only up to about $11 \mathrm{~h}$ at $25{ }^{\circ} \mathrm{C}$ storage condition. The heating process could increase the texture value of the product, and the texture characteristic product would be changing during storage at $4{ }^{\circ} \mathrm{C}$.

\section{REFERENCES}

Agustin, F. and Putri, W.D.R. 2014. Pembuatan Jelly Drink Averrhoa blimbi L. (Kajian Proporsi Belimbing Wuluh: Air dan Konsentrasi Karagenan). Jurnal Pangan dan Agroindustri. 2(3), pp.1-9.

Ainsworth, P.A., and Blanshard, J.M.V. 1979. The Effect of Heat Processing on The Structure and Rheological Properties of Carrageenan Gels. International Journal of Food Science and Technology. 14(2).

Baba, T., Kohno, M. and Hirotsuka, M. 2004. Patent: Jelly Food Containing Soybean 7SProtein. US50959404A.

BPOM. 2016. Pengawasan Klaim pada Label dan Iklan Pangan Olahan.

Gani, Y.F., Suseno, T.I.P., Surjoseputro, S. 2014. Perbedaan Konsentrasi Karagenan Terhadap Sifat Fisikokimia dan Organoleptik Jelly Drink Rosela-Sirsak. Jurnal Teknologi Pangan dan Gizi. 13(2), pp.87-93.

Gasmalla, M.A.A., Yang, R. and Hua, X. 2014. Stevia Rebaudiana Bertoni: An Alternative Sugar Replacer and Its Application in Food Industry. Food Engineering Review. 6, pp. 150-162.

Hartati, F. K. and Djauhari, A. B. 2017. Pengembangan Produk Jelly Drink Temulawak (Curcuma xanthorrhiza roxb.) sebagai Pangan Fungsional. Jurnal Teknik Industri HEURISTIC. 14(2), pp.107-122.

Hugelshofer, A. 1984. Patent: Process for The Production of Soya Jelly and Product Resulting Therefrom. US4564530A.
Kaya, A.O.W., Suryani, A., Santoso, J., Rusli, M.S. 2015. The Effect of Gelling Agent Concentration on The Characteristic of Gel Produced from The Mixture of Semi- refined Carrageenan and Glukomannan. International Journal of Sciences: Basic and Applied Research. 20(1), pp. 313-324.

Kohli, D., Kumar, S., Uphadyay, S., Mishra, R. 2017. Preservation and Processing of Soymilk: A Review. International Journal of Food Science and Nutrition. 2(6), pp.66-70.

Media-Torres, L., Brito-De La Fuente, E., Torrestiana-Sanchez, B., Alonso, S. 2003. Mechanical Properties of Gels Formed Mixtures of Mucilage Gum (Opuntia ficus indica) and carrageenans. Carbohydrate Polymer. 52, pp.143-150.

Nirmagustina, D.E. and Rani, H. 2013. Pengaruh Jenis Kedelai dan Jumlah Air Terhadap Sifat Fisik, Organoleptik dan Kimia Susu Kedelai. Jurnal Teknologi Industri dan Hasil Pertanian. 18(2), pp.168-174.

Nuraeni, I., Proverawati, A., Ulfa, A. 2019. Characteristics of Tamarillo Jelly Drink Using Various Sugar Concentration and The Proportion of Papayas as A Healthy Drink For School Children. Ann Trop and Public Health. 22(11): S356C.

Popescu, C., Iordan, M., Cristian, B. 2007. Structure and Properties of Carrageenan. The Annals Valahia University of Tărgovişte. pp.27-32.

Saniah, K. and Samsiah, M.S. 2012. The application of Stevia as Sugar Substitute in Carbonated Drinks Using Response Surface Methodology. Journal of Tropical, Agriculture and Food Science. 40(1), pp.23-34.

Sardarodiyan, M. and Hakimzadeh, V. 2016. LowCalorie Sweeteners: Science and Energy Balance. BioChemistry: An Indian Journal. 10(4), pp.104. 
Setyaningtum, C., Fernandez, I. and Nugrahedi, R. .2017. Fortifikasi Guava (Psidium guajava l.) Jelly Drink dengan Zat Besi Organik dari Kedelai (Glycine max l.) dan Kacang Hijau (Vigna radiate l.). Jurnal Agroteknologi. 11(01), pp.10-16.

Shurtleff, W. and Aoyagi, A. 2016. History of Modern Soy Protein Ingredients-Isolates, Concentrates, and Textured Soy Protein Products (1911-2016): Extensively Annotated Bibliography and Sourcebook. Soyinfo Center.

Standar Nasional Indonesia. 1994. SNI-Jelly Agar. Available from: http://sispk.bsn.go.id/SNI/DetailSNI/3935

Takaichi, A. and Hatai, R. 1998. Patent: LowCalorie Beverage Composition. WO/2010/050510.

Thomas, W.R. 1997. Carrageenan. In: Imeson, A.P. Thickening and Gelling Agent for Food. Springer. pp.45-59.

Tziboula, A., and Horne, D.S. 2000. Effect of Heat Treatment on k-Carrageenan Gelation in Milk. In: Gums and Stabilisers for the Food Industry. Woodhead Publishing. pp.211-220. 